\title{
The relationship between employer image and employee commitment in family-run hospitality firms
}

\author{
Katrin Schwaiger and Anita Zehrer
}

Katrin Schwaiger is based at the MCI Management

Center Innsbruck, Innsbruck, Austria and Faculty of Geography, University of Cologne, Cologne, Germany. Anita Zehrer is based at MCI Family Business Center, MCl Management Center Innsbruck, Innsbruck, Austria.
Received 15 October 2020 Revised 9 March 2021 16 March 2021

12 July 2021

Accepted 13 August 2021

(c) Katrin Schwaiger and Anita Zehrer. Published by Emerald Publishing Limited. This article is published under the Creative Commons Attribution (CC BY 4.0) licence. Anyone may reproduce, distribute, translate and create derivative works of this article (for both commercial and non-commercial purposes), subject to full attribution to the original publication and authors. The full terms of this licence may be seen at http:// creativecommons.org/licences/ by/4.0/legalcode

\begin{abstract}
Purpose - Among all forms of commitment, affective commitment has been shown to be the most desirable for enterprises. However, research on commitment among employees in family-run businesses in the hospitality industry is scant. To address this gap, this study aims to analyze the impact of employer image components on hospitality employees' affective occupational commitment within family-run businesses. As one can assume specific employer image aspects when studying family-run businesses, this paper expects to achieve a better understanding of the relationship between employer image and employee commitment in this context.

Design/methodology/approach - This study adopts the employer image framework of Baum and Kabst (2013), emphasizing that in addition to considering potential employees, the commitment of current employees needs to be assessed. Convenience sampling is used to obtain a sample from the target population (Tyrolean hospitality and gastronomy employees) from June to September 2018. Multiple linear regression analysis is applied to test the influence of individual employer image constituents on employees' affective occupational commitment.

Findings - Among the five components of the employer image framework applied here, working atmosphere, task attractiveness and payment attractiveness show a significant influence on employees' affective occupational commitment.

Originality/value - This study connects an existing employer image model to employee commitment within the hospitality industry. The findings suggest that the model is applicable to current employees as a key stakeholder group and shows the utility of employer image theory in connection with employee commitment.
\end{abstract}

Keywords Employer image, Hospitality industry, Affective commitment, Family businesses, Tirol

Paper type Research paper

\section{Introduction}

Critical staffing issues have dominated the hospitality industry for several years. There is a consensus in the literature that the hospitality industry suffers from skilled labor shortages and turnover more than other industries (Ferreira et al., 2017; Kim, 2014). Evidence has shown that this situation is aggravated by a generally negative employer image in the industry (Lacher and Oh, 2012). The image of hospitality sector jobs are dominated by unsocial and long working hours, the lack of work-life balance, low wages and a relatively low social status (Deery and Jago, 2009; Ineson et al., 2013; Richardson, 2010). Although this negative image applies to hotel chains and family-run businesses alike, family businesses differentiate themselves from nonfamily businesses with respect to employer image. Studies refer to the coexistence of family and business (Chrisman et al., 2008), specific communication behaviors within companies (Leiß and Zehrer, 2018) and a more social work environment and career longevity (Chang et al., 2010) within family-run businesses. In general, a positive employer image is particularly important in two regards: 
potential employees are influenced by employer image in deciding whether to apply to a specific employer or job (Lievens and Slaughter, 2016) and employer image affects whether existing employees want to continue in their current career (Leekha et al., 2014). Employee turnover in family-run firms is typically slightly lower than that in nonfamily firms (Bacon et al., 2013). According to Kachaner et al. (2012), the annual turnover in a family-run firm is approximately $9 \%$, compared to $11 \%$ in nonfamily firms. However, as shown in Brown et al. (2015), many hospitality employees who leave their positions leave the industry altogether.

Separate from image theory, another dominant theory regarding employee behavior is commitment theory. According to Meyer and Allen (1991), organizational commitment can be divided into three subcomponents, namely, affective, normative and continuative commitment. Affective commitment refers to whether or not employees want to pursue a career with a specific employer or in a specific occupation (Tang et al., 2012). Employees with high affective commitment have a higher likelihood of contributing to organizational performance and doing more in their jobs than is expected of them; as a result, affective commitment may be considered the most desirable of the three components for an organization (Kazlauskaite et al., 2006). This finding has been confirmed by other studies that have identified affective commitment as the most important contributing factor in occupational commitment (Kurd et al., 2017; Meyer and Herscovitch, 2001; Snape and Redman, 2003; Weng and McElroy, 2012) and is even more critical for family-run businesses that focus on maintaining long-term relationships with their employees. Therefore, encouraging affective commitment is a dominant issue for family-run hospitality businesses (Sieger et al., 2011), as a negative employer image is relevant for both family and nonfamily businesses.

A connection between employer image and employee commitment has been established in the literature, with evidence showing that an employer's perceived external prestige, that is, what employees think outsiders think about their work or their company, is related to effective commitment (Rego et al., 2010). Positive perceptions of an employer's brand image have a positive influence on employee satisfaction and loyalty, and therefore on employee commitment (Davies et al., 2018; Priyadarshi, 2011). An employer may adopt branding strategies to create a unique image to differentiate itself from its competitors (Akuratiya, 2017). This is crucial, as employees who are engaged and loyal to an employer brand tend to be committed employees (Backhaus and Tikoo, 2004). The affective commitment component of organizational commitment is especially important with regard to specific professions within companies. This relationship is not well researched, particularly with respect to a focus on occupational affective commitment, representing an additional gap in the literature. Therefore, this study analyzes the impact of employer image on this aspect of occupational commitment.

In light of the above, it is clear that current employees (as distinct from potential job applicants) have not been studied adequately with respect to the impact of commitment and family-run hospitality businesses. Baum and Kabst (2013) applied their employer image model to potential employees' intent to apply for a job with an organization, whereas preliminary research offers only limited information on the influence of employer image and its constituents on tourism industry employees' commitment. Regarding family-run businesses, specific aspects of an employer's image can be assumed and we intend to achieve a better understanding of the relationship between employer image and employee commitment in this context. This study extends the existing literature and contributes to the theory by testing Baum and Kabst's (2013) model in a different context, applying it to current employees in family-run hospitality firms and their present level of commitment, instead of focusing on prospective employees' intention to apply. As a lack of skilled labor affects not only a specific organization but all jobs in the hospitality industry, it is important to explicitly study employees' occupational commitment. Furthermore, the components in the employer image model are used here to address the particulars not only of a specific 
employer but also of the job itself (e.g. task attractiveness and payment attractiveness). Therefore, the leading research question in this study is as follows:

$R Q 1$. How do individual constituents of employer image influence employees' affective occupational commitment in family-owned hospitality firms?

The remainder of this study is organized as follows: Section 2 presents the existing research in the area of employer image and commitment theory and develops our hypotheses. Section 3 describes the data and methodology used to apply and test Baum and Kabst's (2013) model using multiple linear regression analysis to analyze the relationship between elements of employer image and affective commitment. Section 4 presents the results of the analysis, discusses the findings, describes the study limitations, highlights implications for practitioners and suggests areas of further research. Our study contributes to a better understanding of employer image and affective commitment in the context of family-owned hospitality businesses and concludes the paper in Section 5.

\section{Literature review and research hypotheses}

\subsection{Employee commitment}

Becker (1960) described the commitment as "side bets" that an individual makes within different value systems in his or her own personal world. Porter et al. (1974, p. 604) described the commitment as a multifaceted construct that consists of "a strong belief in and acceptance of the organization's goals and values; a willingness to exert considerable effort on behalf of the organization; and a definite desire to maintain organizational membership." O'Reilly and Chatman (1986) conceptualized commitment as a congruence between individual and organizational values, thus classifying commitment as a form of psychological attachment that depends on compliance for extrinsic rewards. The dominant concept in the literature is the three-component model of commitment in Meyer and Allen (1991). The authors' divided commitment into an affective component (why someone wants to stay in a company or job), a continuative component (why someone needs to stay in a company or job) and a normative component (why someone feels an obligation to stay in a company or job). Meyer et al. (1993) introduced a six-item scale to measure commitment that refers to both organizations and occupations, extending organizational commitment to the domain of occupations and validating their scale. Generally, commitment may be defined as a "force that binds an individual to a target (social or non-social) and to a course of action of relevance to that target" (Meyer et al., 2006, p. 666).

Preliminary literature has highlighted commitment as one of the most important variables in understanding employees' work behavior (Dhar, 2015; Mowday et al., 1979). Commitment has been shown to be negatively related to employee turnover (Kazlauskaite et al., 2006) and as such, is seen as a key success factor for business performance (Alniacik et al., 2011). Commitment to an organization has been the subject of a wide body of research. Meyer and Maltin (2010) analyzed the effects of commitment on employee well-being. They argue that effective organizational commitment positively influences employees' well-being by reducing workplace stressors, whereas the opposite is true for continuative and normative commitment. Similar results were provided by Jain et al. (2009), who studied manufacturing employees. Other studies have found a strong relationship between employees' commitment and their motivation and level of satisfaction (Meyer et al., 2006; Yousef, 2017).

Although organizational and occupational commitment overall, including all three components, has been researched thoroughly, several studies have placed a particular emphasis on the affective component (Alniacik et al., 2011; Brown, 1996; Mehmood, 2016; Mercurio, 2015). Relative to the other two components, studies show affective commitment to be the most reliable and the most strongly validated dimension of organizational commitment (Solinger et al., 2008), with the greatest content and face validity (Brown, 1996; 
Cohen, 2003). Furthermore, organizations view affective commitment as the most desirable type of commitment, as employees with a high degree of affective commitment are more likely to contribute to organizational performance and do more than what the firm expects of them (Kazlauskaite et al., 2006). This is essential, given that employees are the most important stakeholders influencing a firm's survival (Kurd et al., 2017).

Mercurio (2015) identified affective commitment as the core essence of the organizational commitment construct, stating that it is the most influential form of commitment and strongly affects employee behavior and reactions to transactions with the organization. With a focus on occupational commitment, Kurd et al. (2017) assessed 222 health workers and found that the workplace and the social environment positively influence affective commitment. They highlight affective commitment as the most important independent variable of occupational commitment. Johnson et al. (2010) showed that developing affective commitment requires an alignment of employees' own values and goals with those of a specific workgroup. Weng and McElroy (2012) assessed how effective occupational commitment impacts the relationship between career growth within an organization and turnover intentions using a sample of 396 managers. Organizational career growth was found to explain significant variations in levels of affective occupational commitment. Similarly, affective commitment to occupation has been shown to be positively related to employees' intention to participate in professional activities and negatively related to occupational withdrawal intentions (Snape and Redman, 2003). Among the three commitment components, affective commitment is the strongest predictor of these intentions. Moreover, Meyer and Herscovitch (2001) showed that employees' focal behavior is broader in the case of affective commitment than with the other two components and affective commitment predicts a wider range of employee behaviors. They provided a general explanation as to why affective commitment is correlated with a wider range of behavioral outcomes, stating that if commitment is accompanied by a mindset of desire, an individual employee perceives the behavioral consequences of commitment more broadly than when one's mindset is dominated by perceived cost or obligation. Taking preliminary works into account, it is evident that employee commitment has not been a focus of family business research, particularly with respect to the hospitality industry, where employer image is a particularly problematic issue.

\subsection{Employer brand and image in a family business context}

Ambler and Barrow (1996, p. 187) defined the employer brand as a "package of functional, economic and psychological benefits provided by employment and identified with the employing company." Therefore, employer branding is seen as a central tool to attract potential employees (Sivertzen et al., 2013). However, such branding not only affects potential employees but also targets current employees' motivation to actually "live the brand" (Maxwell and Knox, 2009). Furthermore, it aids as a communication tool for current employees, affecting an employer's ability to attract and retain employees (Sokro, 2012). Employer branding generally attempts to build an image of the organization as a good place to work (Khanolkar, 2013). We note that the terms "employer brand" and "employer image" have been used synonymously in the literature (Cable and Turban, 2001; Ewing et al., 2002); hereafter, the term "employer image" is used consistently.

The family-run hospitality industry is particularly susceptible to a shortage of skilled employees and is considered to have a negative employer image industry-wide (Lin et al., 2018). Jauhari et al. (2012) recognized the hospitality industry's need to develop a differentiated organizational value proposition, to separate the individual employer's brand from the poor employer image of the overall industry. Substantial value is attributed to the brand of a family-owned firm (Krappe et al., 2011). Its distinctive features originate from the family history, members and identity, which, in turn, have a bearing on the firm's culture and organizational image (Astrachan et al., 2018; Craig et al., 2008; Zellweger et al., 2010). 
Given this study's specific focus on family businesses, we note that employer image for such businesses includes certain features not found in non-family businesses. Family-run businesses are defined as businesses "governed and/or managed with the intention to shape and pursue the vision of the business held by a dominant coalition controlled by members of the same family or a small number of families in a manner that is potentially sustainable across generations of the family or families" (Chua et al., 1999, p. 25). Such businesses are typically characterized by specific sustainability efforts, strong familybusiness ties, stability and social working conditions with a discernable focus on loyalty and long-term relationships with employees (Chrisman et al., 2008; Hauswald et al., 2016; Krappe et al., 2011). A strong family culture sometimes impedes the enterprise's economic performance (Bertrand and Schoar, 2006); however, it is precisely these family ties that contribute to a specific canon of values shaped by honesty and respect (Stewart, 2003). Another aspect to highlight in the context of research on family businesses is socioemotional wealth as opposed to financial values, which goes hand in hand with the particular traits of employer image with respect to family businesses. It has been argued that in family firms, preserving socio-emotional wealth takes precedence over the pursuit of financial goals (Gómez-Mejia et al., 2007; Martin and Gómez-Mejia, 2016). Family businesses gain from socio-emotional wealth by maintaining family control, enjoying feelings of altruism and an enhanced reputation of or identification with the firm (Martin and Gómez-Mejia, 2016). General motivations for valuing socio-emotional wealth include family control of the firm and emotional attachments (Swab et al., 2020). In fact, it is the nonmonetary values, such as work environment, mentoring, respect and appreciation, that are associated with and support the image of a family business (Dhaenens et al., 2018; Kumar and Shekhar, 2012; Mooney et al., 2016). These behaviors, along with the appeal of socio-emotional wealth in family firms and their image focus, support affective commitment, making employees want to remain in their profession with the family firm.

The components of employer image have been used in recent research to predict potential employees' intention to apply for a position with a company. In their cross-national study on the largely family-run hospitality industry, Baum and Kabst (2013) found that the employer image components of the work atmosphere, career opportunities, work-life balance, task attractiveness and payment attractiveness influence prospective employees' intention to apply. Their research model was used by Danler and Zehrer (2017) in a hospitality industry context. Consistent with Baum and Kabst's (2013) findings, Danler and Zehrer (2017) found career opportunities and task attractiveness to have the strongest influence on the intention to apply. However, current employees need to be addressed separately, as they do not evaluate their own organization's image in the same way that potential employees do (Maxwell and Knox, 2009). Therefore, there is a need for further research on the connection between employer image, affective occupational commitment and family businesses.

\subsection{Employer image and employee commitment}

In the context of commitment research, there appears to be a consensus that the individual components of employer image influence current employees' commitment (Herrbach and Mignonac, 2004; Khanolkar, 2013; Ito et al., 2013; Priyadarshi, 2011). As mentioned above, the affective component has been highlighted as particularly desirable (Kazlauskaite et al., 2006; Kurd et al., 2017). Employees have two images about their employer, one internal and the so-called construed external image, which refers to what employees think outsiders think about their company (Dutton and Dukerich, 1991). Therefore, a company's perceived external prestige may also influence employees' affective commitment. Herrbach and Mignonac (2004) assessed 527 managers in France using hierarchical regression analysis and showed that the perceived external prestige of a company influences employees' job satisfaction, affective well-being and affective organizational commitment. Similar findings were obtained by Rego et al. (2010). 
Recent research has focused on the influence of employer image on employee commitment. Most of these studies found that specific aspects of employer image contribute to employee commitment. For example, Kimpakorn and Tocquer (2009) analyzed 320 hotel employees and found that the human resources practices aspect of employer image influences how employees develop affective commitment. Similarly, although in another industry, Ito et al. (2013) conducted a study of 166 employees in childcare centers in Canada and found that organizational values and job security have a significant influence on affective commitment. In addition, Priyadarshi (2011) found that the career development and income constituents of employer image influence the affective organizational commitment of executives in various organizations in Delhi. As in Priyadarshi (2011), as well as Herrbach and Mignonac (2004), most of these studies focused on the impact of employer image on organizational commitment. We, therefore, expect employer image to influence occupational commitment, which we test in this study.

However, the hospitality industry is characterized by a lack of skilled labor, making the issue of commitment particularly relevant compared to other industries, not only for individual employers but also for the entire industry (Lacher and Oh, 2012). The negative aspects of the industry's image, for example, low compensation and/or long working hours, lead to high employee turnover and to employees leaving the industry altogether (Brown et al., 2015). Therefore, it is not only commitment to the organization that needs to be addressed but also a commitment to the professions that employees might pursue in the hospitality industry, which we identify as a gap in the existing literature. Brown et al. (2015) emphasized that employees committed to their jobs are more likely to stay in the industry. It has also been suggested that employers should support their employees' occupational identity (Mooney et al., 2016). This is particularly important for family-run businesses that value long-term employment relationships with their employees. Targeting affective commitment is, therefore, a central issue for familyrun hospitality businesses (Sieger et al., 2011). Regarding the industry's negative image as an employer in society overall, this is an issue for the entire hospitality industry regardless of whether a business is family-run or not. For these reasons and based on evidence from the abovementioned studies, we formulate the following hypotheses:

H1. Working atmosphere is positively related to affective occupational commitment in small hospitality family firms.

H2. Career opportunities are positively related to affective occupational commitment in small hospitality family firms.

H3. Work-life comfort is positively related to affective occupational commitment in small hospitality family firms.

H4. Task attractiveness is positively related to affective occupational commitment in small hospitality family firms.

H5. Payment attractiveness is positively related to affective occupational commitment in small hospitality family firms.

The review of the literature on employer image and commitment theory discussed above resulted in the proposed research design shown in Figure 1.

This conceptual framework posits a positive relationship between these employer image constituents (working atmosphere, career opportunities, work-life comfort, task attractiveness, payment attractiveness) and affective occupational commitment.

\section{Methodology}

\subsection{Survey instrument}

To gather our data, we used a questionnaire consisting of four sections focusing on the respondent's perceptions of specific employer image factors, affective occupational 


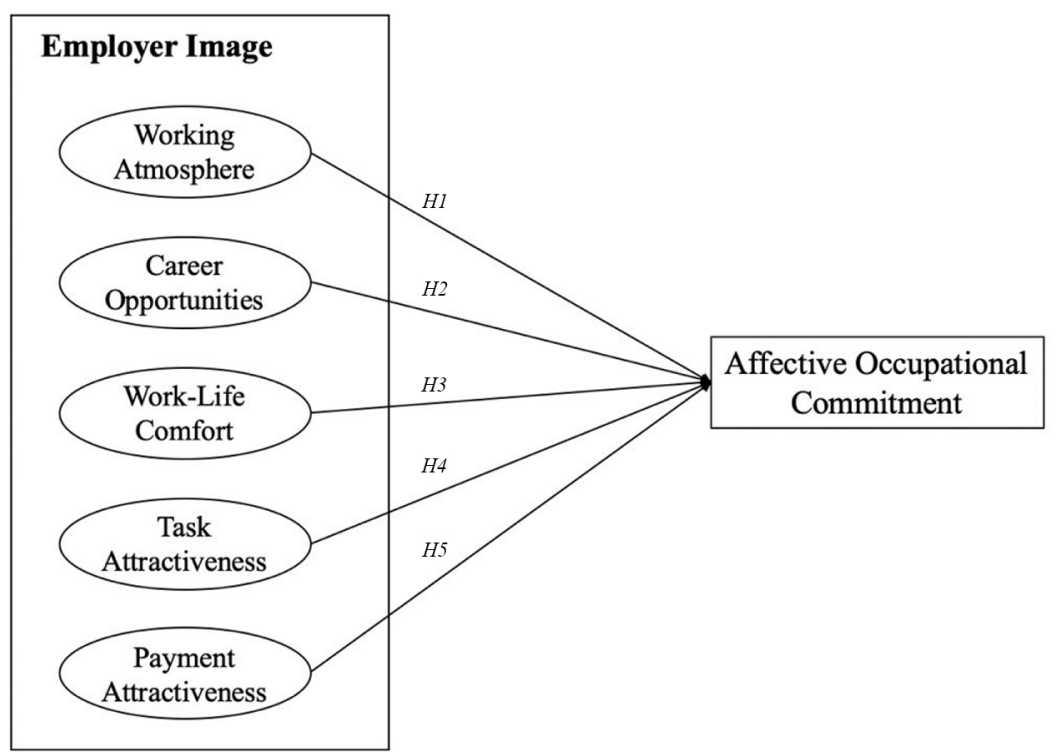

Source: Based on the framework by Baum and Kabst (2013)

commitment, satisfaction with different facets of the workplace and sociodemographic details. The questionnaire was based on common recommendations (Bryman and Bell, 2011) and was written in German. Items taken from studies published in English were translated into German by a bilingual native speaker. The questionnaire was designed so that answers would be self-reported. To decrease the potential for a common method bias, different variables were given different response formats. Furthermore, the questionnaire clearly separated the independent and dependent variables by placing them on different pages (Podsakoff et al., 2003). We pilot-tested our survey among a group of volunteer participants consisting of students, faculty and staff members in a hospitality industry educational program, as well as hospitality employees. Using this pilot test, we checked for difficulties or problems in the questionnaire. We ensured that no data or intended meaning was lost from the items originally written in English as we had them translated by a bilingual native speaker and determined that both versions were understood by several participants before distributing the final questionnaire. After adjusting two questions that created some confusion or ambiguity among the respondents, we approached the actual data-collection phase. Problems of nonresponse bias, common method bias and reliability were not a concern. Nonresponse bias was not an issue as all questions had to be answered to move to the next page and to submit the final results. Regarding common method bias, we applied Podsakoff et al.'s (2003) procedural remedies by using different response formats for different variables and separated the dependent and independent variables on different pages in the questionnaire.

\subsection{Sample and data collection}

The target population in this study consists of employees in the Tirolean hospitality and gastronomy industry. Family businesses dominate the hospitality industry in Tirol (Peters and Kallmuenzer, 2018), and thus play a vital role in the region's economy. In total, $85 \%$ of all businesses in Tirol are family-owned and family businesses comprise 92\% of the region's hospitality industry. Therefore, these businesses are the backbone of the Tirolean hospitality 
industry (Mandl, 2008). Furthermore, the region is strongly dependent on tourism; without tourism, gross value-added in Tirol would be $23.9 \%$ lower and 24.5\% fewer people would be employed (Stadler et al., 2016). The non-probability-based sampling method, convenience sampling, was used to obtain the data. The questionnaire was distributed online with the help of the Austrian Federal Economic Chamber and data were collected between June and September 2018. After data cleansing and elimination of incomplete questionnaires, 230 valid responses were available to use in our quantitative analysis.

\subsection{Measures}

Employer image: Employer image was assessed based on the framework in Baum and Kabst (2013). It includes the image variables of working atmosphere, career opportunities, work-life balance, task attractiveness and payment attractiveness. Some items pertaining to the image variable were modified slightly to reflect the characteristics of the hospitality industry. For example, task attractiveness included an item on the pleasure of working with people. As another example, "I am satisfied with my team" represented the working atmosphere variable. Work-life balance was represented by a single item in this study, "working hours," which is one of the most problematic facets of the hospitality industry with respect to achieving an acceptable work-life balance (Deery and Jago, 2009; Richardson, 2010; Tuzunkan, 2018). The respondents indicated their level of agreement or disagreement with the statements using a five-point Likert scale ranging from $1=$ "strongly agree" to 5 = "strongly disagree."

Commitment: To measure affective occupational commitment, we used a four-item scale adapted from Meyer and Allen (1991). A sample item in this section was "I take pride in my work." Respondents were asked to indicate their agreement with the items focused on commitment on a five-point Likert scale ranging from $1=$ "strongly agree" to $5=$ "strongly disagree."

Controls: Age, gender and affiliation were included as control variables to account for the possibility that variables other than those described above could explain differences in the relationships between the dependent and independent variables. All control variables were dummy coded. No moderating effect from age, gender or affiliation was found in the multiple regression analysis.

\section{Analyses and results}

\subsection{Data analyses}

We used principal component analysis to determine the factor loadings for each variable (Table 1). Scale reliability was tested using Cronbach's $\alpha$ and, except for the variable of task attractiveness, Cronbach's $\alpha$ was well above the proposed threshold of 0.7 (Hair et al., 1998). Task attractiveness had a Cronbach's $\alpha$ value of 0.65 , which was slightly below the threshold. However, it has been stated that if constructs are measured using only a small number of items, internal consistency is usually lower than when a large number of items is used (Cortina, 1993). In such cases, values above 0.6 may still be viewed as acceptable.

The data were checked for autocorrelation by conducting the Durbin-Watson test, which resulted in a value of 1.586. Autocorrelation is, therefore, unlikely. To test for multicollinearity, tolerance levels and variance inflation factors (VIFs) were calculated. Tolerance levels were above 0.2 and VIF values were well below the threshold of 10 (Table 4), which makes multicollinearity in the data highly unlikely (Aiken and West, 1996).

\subsection{Respondent profiles}

Table 2 shows the demographic characteristics of the 230 respondents. Close to two-thirds (62.3\%) were female, whereas $1.7 \%$ declined to specify their gender. In terms of age, the 
Table 1 Measurement of variables, confirmatory factor analysis and reliability analysis

\begin{tabular}{llcc} 
Items & Variables & Factor loadings & Cronbach's $\alpha$ \\
\hline Taking pride in work & Affective commitment & 0.92 & 0.89 \\
Being enthusiastic about work & & 0.90 & \\
Enjoying work & & 0.88 & \\
Work important for self-image & Working atmosphere & 0.80 & 0.89 \\
Relationship with supervisor & & 0.78 & \\
Relationship with team & & 0.74 & \\
Pleasant working atmosphere & Task attractiveness & 0.45 & 0.65 \\
Attractive work & & 0.73 & \\
Working with people & & 0.73 & 0.80 \\
Interesting/varied tasks & Career opportunities & 0.65 & \\
Good opportunities for development & & 0.73 & \\
Good opportunities for promotion & & 0.88 & - \\
Good education/training & Payment attractiveness & - & - \\
Attractive payment options & Work-life comfort & - &
\end{tabular}

\section{Table 2 Respondent profile $(n=230)$}

\begin{tabular}{llr} 
Variables & Subgroups & \% of total \\
\hline Gender & Male & 62.3 \\
& Female & 35.9 \\
Age (years) & Not specified & 1.7 \\
& $<20$ & 41.6 \\
& $20-29$ & 39.4 \\
& $30-39$ & 10.8 \\
Affiliation & $40-49$ & 6.1 \\
& $>50$ & 2.2 \\
& Hotel & 90.9 \\
& Gastronomy & 9.1
\end{tabular}

largest percentage (41.6\%) was less than 20 years, whereas $39.4 \%$ was between 20 and 29 years. Only $2.2 \%$ were older than 50 years. All respondents worked in small- and medium-sized family firms (fewer than 249 employees). Most respondents worked in hotels (90.9\%), whereas $9.1 \%$ worked in the gastronomy field (i.e. restaurants, cafes, etc.).

\subsection{Regression analyses}

To test the hypotheses proposed in this study, we conducted multiple regression using the SPSS statistics program, creating a model of how employer image influences affective occupational commitment. The model's coefficient of determination $\left(R^{2}\right)$ indicated that $66 \%$ of the variation in affective occupational commitment was explained by the independent variables pertaining to employer image captured by the model. The beta coefficients indicated that three of the five variables significantly influenced affective occupational commitment: working atmosphere (Sig. 0.000), task attractiveness (0.000) and payment attractiveness (0.006). The largest contribution was made by working atmosphere $(\beta=0.402)$, followed by task attractiveness $(\beta=0.348)$ and payment attractiveness $(\beta=0.134)$. Thus, $H 1, H 4$ and $H 5$ were supported. The model results led us to reject $\mathrm{H} 2$ and $H 3$, as there was no significant relationship between effective occupational commitment and career opportunities (Sig. 0.146; $\beta=0.095$ ) or work-life balance (Sig. 0.645; $\beta=-0.021$ ).

The highest agreement among the responses to questions about employer image was seen for the working atmosphere $(\mu=1.92)$ and task attractiveness $(\mu=2.06)$ variables, as 
shown in Table 4. Working atmosphere and affective commitment were found to have a slightly higher correlation $\left(0.732^{* *}\right)$ than that among other variables (Table 3$)$. As noted previously, multicollinearity is probably not a concern because of the fully acceptable tolerance levels and VIF values (Table 4).

Figure 2 provides a graphic overview of the research design that includes these results.

\section{Discussion and conclusions}

The main purpose of this study was to contribute to the understanding of how employer image relates to affective occupational commitment. We used the tourism destination of Tirol as a research setting, as the hospitality sector plays a particularly important role in this region (Stadler et al., 2016). Our primary goal was to enrich the body of research on employer image and commitment by applying the employer image framework in Baum and Kabst (2013) to family-run businesses in the hospitality industry. Our results indicated that various elements of employer image influence affective occupational commitment in different ways, demonstrating the applicability of the framework. Furthermore, we addressed two gaps in the literature. First, it has been stated that actual hospitality employees, as opposed to tourists or potential employees, are under-researched (Baum, 2018). The majority of studies on this topic focus on potential employees' perceptions of employer images (Danler and Zehrer, 2017; Lievens and Slaughter, 2016; Sivertzen et al., 2013). In contrast, we specifically addressed current employees' perceptions. Second, given the specific employer image attributes of family-run businesses (long-term focus, social working conditions, sustainability) and their focus on socio-emotional wealth (GómezMejia et al., 2007), it is worth analyzing the relationship between employer image and employee commitment. Affective commitment in the context of a family-run business has also largely been omitted by existing studies. The importance of this omission can, again, be evaluated based on facets of employer image specific to family-run businesses. Third, based on our understanding, insights into the nature of the link between employer image

Table 3 Correlations between dependent and independent variables

\begin{tabular}{|c|c|c|c|c|c|c|}
\hline & $\begin{array}{c}\text { Affective } \\
\text { commitment }\end{array}$ & $\begin{array}{c}\text { Working } \\
\text { atmosphere }\end{array}$ & $\begin{array}{c}\text { Task } \\
\text { attractiveness }\end{array}$ & $\begin{array}{c}\text { Career } \\
\text { opportunities }\end{array}$ & $\begin{array}{c}\text { Payment } \\
\text { attractiveness }\end{array}$ & $\begin{array}{l}\text { Work-life } \\
\text { comfort }\end{array}$ \\
\hline Affective commitment & 1 & & & & & \\
\hline Working atmosphere & $0.732^{* *}$ & 1 & & & & \\
\hline Task attractiveness & $0.637^{* *}$ & $0.615^{* *}$ & 1 & & & \\
\hline Career opportunities & $0.633^{* *}$ & $0.691^{* *}$ & $0.674^{* *}$ & 1 & & \\
\hline Payment attractiveness & $0.472^{* *}$ & $0.441^{* *}$ & $0.4566^{* *}$ & $0.578^{* *}$ & 1 & \\
\hline Work-life balance & $0.367^{* *}$ & $0.406^{* *}$ & $0.472^{* *}$ & $0.472^{* *}$ & $0.363^{* *}$ & 1 \\
\hline
\end{tabular}

\section{Table 4 Mean, standard deviation, multicollinearity and regression results}

\begin{tabular}{lcccccc} 
Variables & $M(\mu)$ & $S D$ & $\beta$ & Sig. & Tolerance & VIF \\
\hline Working atmosphere & 1.92 & 0.882 & 0.402 & 0.000 & 0.481 & 2.079 \\
Task attractiveness & 2.06 & 0.768 & 0.348 & 0.000 & 0.463 & 2.161 \\
Career opportunities & 2.33 & 0.967 & 0.095 & 0.146 & 0.348 & 2.870 \\
Payment attractiveness & 2.73 & 1.158 & 0.134 & 0.006 & 0.621 & 1.611 \\
Work-life balance & 3.55 & 1.119 & -0.021 & 0.645 & 0.702 & 1.424 \\
Notes: Dependent variable: affective commitment; $n=230 ; R^{2}=0.663$ & &
\end{tabular}




\section{Figure 2 Results}

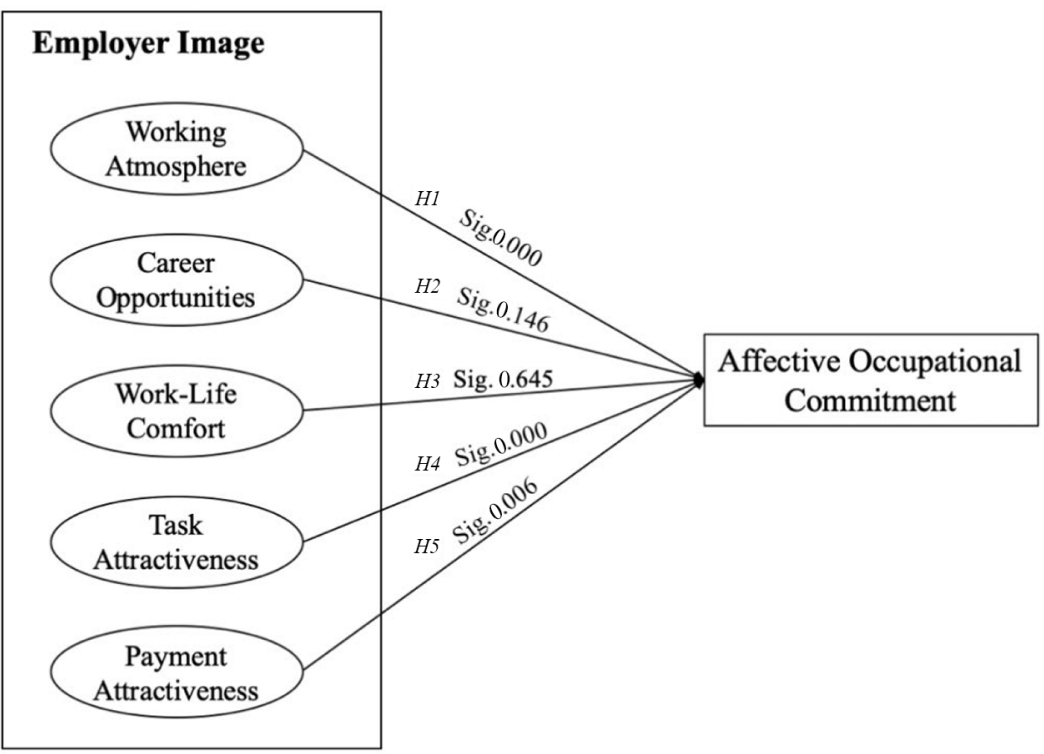

Source: Based on the framework by Baum and Kabst (2013)

and employee commitment are still limited. In that regard, our study may be seen as a point of departure for further research on this topic, offering several important findings regarding the integration of employer image and commitment research.

The regression model generated from our data showed that working atmosphere $(H 1)$, task attractiveness $(H 4)$ and payment attractiveness $(H 5)$ have a positive, significant relationship with employees' affective organizational commitment. This support for $\mathrm{H} 1$ is consistent with Ito et al. (2013), who argued that organizational values and job security have a significant influence on affective commitment. Organizational values are essential to creating a supportive and positive work atmosphere as their impact ranges from the senior management level to team building and team structures. Similarly, Kimpakorn and Tocquer (2009) found that human resource practices in the service sector impact employees' affective commitment. In our model, the working atmosphere had the largest influence on affective commitment $(\beta=0.402)$. This is consistent with Baum and Kabst's (2013) outcome, showing that work atmosphere, along with career opportunities, was the most important factor in predicting prospective employees' intention to apply in all the countries assessed in their study, whereas other factors were country-specific. Our result is also in accordance with the specific image of family-run businesses, as existing studies show that a social and constructive working atmosphere, along with career longevity, characterizes this type of business (Chang et al., 2010; Mooney et al., 2016). Dhaenens et al. (2018) mentioned mentoring as a strong influencing factor of employees' commitment to family-run businesses. In general, it appears likely that the nonmonetary components of employer image present in family-run businesses enhance affective occupational commitment. Thus, it is clear that the working atmosphere is important not only for potential employees and their decision to pursue a career with an employer but also for current employees' commitment building. Our results add to the understanding of the critical role of working atmosphere for employee commitment, which in the long run may help to reduce negative behavioral outcomes, such as turnover. 
Our study also found task attractiveness to be a significant influencing employer image factor; therefore, $\mathrm{H} 4$ is accepted. This finding is in line with and advances the results in Danler and Zehrer (2017), which identified task attractiveness as one of the most essential factors impacting young employees' intention to apply. This study directly tested the impact of task attractiveness on affective occupational commitment and the positive, significant results are logical: if employees are satisfied with their tasks and perceive them to be attractive, those employees are more likely to commit themselves to those tasks. Furthermore, our study supports the findings of previous research regarding the influence of pay attractiveness (H5). For example, consistent with Priyadarshi (2011), pay attractiveness was found to be a significant factor impacting affective commitment. It must be noted that Baum and Kabst (2013) found pay attractiveness to be the least influential factor in their model, which is consistent with our results. However, an employee's pay obviously influences his or her affective occupational commitment to some extent. A possible explanation for this result may be that work in the hospitality industry is perceived as stressful and the workload as high. In addition, the working hours are often long, unpredictable and incompatible with maintaining a social or family life. Therefore, adequate pay may compensate for the perceived disadvantages of jobs in the hospitality industry, thereby enhancing the feeling of wanting to be in the job, in other words, enhancing affective commitment.

In contrast, H2 was rejected, as we found that career development had no significant influence on affective occupational commitment. This deviates from the finding in Danler and Zehrer (2017) where career opportunities as an image factor, along with task attractiveness, had the strongest influence on potential applicants' intention to apply for a job. Similarly, in Baum and Kabst (2013), the image factor "career opportunities" was shown to be one of the most important influencing factors across different countries. This difference between our results and those of previous studies could be explained as follows. First, the aforementioned studies assessed potential employees and their intentions to work for a specific business. At this stage of the career process, career opportunities and perception of advancement opportunities appear to be a central issue. If an individual has already been employed in a firm for some time, the focus may shift from a strongly careeroriented perspective toward the need to be satisfied with and committed to one's work. Furthermore, we emphasize that our study was conducted among family-run businesses. Employees in these businesses may tend to value stability and being appreciated over continuous career development. Nonetheless, opportunities for career development may still play a role. Still, as this study analyzed the impact of such opportunities on affective commitment, it is likely that building a career is not the primary commitment trigger; what matters most is the nature of the job itself and whether it is perceived as attractive.

The most surprising result was the rejection of $H 3$. The image factor of work-life balance contributed the least to employees' occupational affective commitment (Sig. 0.645; $\beta=-0.021)$. This outcome was particularly unexpected as this factor, mostly represented by good working hours, is one of the most central negative aspects of employer image in the hospitality industry (Deery and Jago, 2009; Lacher and Oh, 2012). Tuzunkan (2018) highlighted that the long and irregular working hours in the hospitality industry may be detrimental to hospitality employees' family lives, particularly when accompanied by inadequate pay. This result was confirmed by Richardson (2010). Nevertheless, the worklife balance factor did not influence affective commitment in our study. An explanation for this result could be that working hours as a measure of work-life balance may not be directly related to job commitment. Employees may be affectively committed to their jobs while at the same time perceiving the long working hours as negative; in other words, they simply like what they do in their jobs, regardless of the circumstances. This may also be a function of our sample, which consists of hospitality employees working in family-run firms. In other words, the positive nature of the job may overcome the negative aspects, in terms of 
affective commitment. This is consistent with the acceptance of $H 4$, as task attractiveness was found to be one of the two most important influencing factors.

Our study faces some limitations that are important to note. The first limitation pertains to its sectoral and regional scope. Although the questionnaire respondents were distributed across Tirol, it is important to keep in mind that participants' responses are tied to what they expect from jobs in the hospitality sector in this specific region. For example, the results might differ if respondents were located in other parts of Austria or other European countries. We did not check for cross-cultural differences, as in Baum and Kabst (2013). Thus, conceptual revisions and other empirical analyses may be needed to create a more complete profile of employees' perceptions and to see whether our results hold across employees of different nationalities in Tirol. Additionally, the study focused exclusively on the hotel and gastronomy sectors within the hospitality industry. Other tourist-facing industries, such as retail or ropeway facilities that have different working conditions, may differ in terms of what influences affective commitment.

Another limitation concerns the generalizability and representativeness of our findings. The research design may not be generalizable to other countries with different political or cultural backgrounds. For example, in Tirol, there are specific predispositions regarding the economic and political environment that are not comparable to less developed countries. In the latter, affective commitment might not play such an important role compared to what is a rather self-fulfillment-driven region of the world. If a similar analysis was carried out in a destination with a different culture and value system, different employer image factors might influence affective commitment. An indication that this might be the case is the variation across cultures found in Baum and Kabst's (2013) study. Furthermore, the survey scale used in our study cannot be directly applied to other sectors, such as childcare (Ito et al., 2013). The scale used in Baum and Kabst (2013) was altered slightly for this study to make it applicable to the hospitality industry. For example, given that working with people is a central aspect of jobs in the hospitality industry, this aspect was included in task attractiveness. In addition, the survey may not be represented as we apply convenience sampling, resulting in a rather small sample of 230 employees. Nevertheless, we believe that this study contributes to the literature by enhancing the understanding of employer image and its relationship to employees' affective occupational commitment.

To enhance the understanding of the relationship between employer image and employee commitment, we propose several areas of further research: first, it would be worthwhile to analyze a larger sample within a single country. This would provide an opportunity to assess differences between different provinces/regions and nationalities of workers, their tenure with a firm and the firm's age and tradition, to create a more thorough respondent profile. Second, an interesting area to pursue would be to test the applicability of the employer image framework to occupational commitment in other industries within and outside the tourism industry, modifying the scales as needed to match the key characteristics of other sectors. Third, nonfamily businesses could be analyzed to provide a control group to compare to the results in this study. Finally, qualitative analyses could prove fruitful in understanding the reasons why certain image factors play a more or less important role in employees' commitment or if there are other factors that were not included in Baum and Kabst's (2013) framework but might explain employees' commitment equally well.

This study also yields valuable information for employers in the hospitality industry, where the lack of skilled labor poses a major challenge. Research has emphasized the importance of the effect a positive employer image has on employees' desire to remain with a particular business and may have a strong influence on their commitment (Ito et al., 2013; Leekha et al., 2014; Priyadarshi, 2011). Therefore, and particularly in times of challenging staffing issues, it is important for hospitality business owners to pay close attention to factors that may increase their employees' commitment. As affective commitment is the most desirable form of commitment (Kazlauskaite et al., 2006), a specific focus on enhancing this 
component is recommended. This study highlights task attractiveness, working atmosphere and pay attractiveness as highly significant factors influencing affective occupational commitment. Practitioners may want to take measures to improve these aspects in their businesses. Job rotation, appropriately augmented pay and an open and trustful communication culture are only some of the measures likely to increase employees' affective occupational commitment. This would increase employees' emotional attachment to the company and enhance their identification with company goals, resulting in greater employee satisfaction; it might even decrease turnover in the long run. Employees who are affectively committed to a firm are likely to act as ambassadors, and thus become a great asset to the company. Furthermore, the study results might help the marketing departments of family-run firms as well as the entire hospitality industry, particularly with respect to creating awareness of an employer brand in the employment market, as we know that prospective employees are willing to consider lower salaries if the employer has a good reputation (Cable and Turban, 2001). For example, employer image campaigns could work to improve brand perceptions. Regarding employer image campaigns on social media channels, the top 1,000 German companies and their job candidates were found to use Facebook (29.9\%), followed by Instagram (24.4\%), Xing (18.1\%), Linkedln (12.4\%), YouTube (9.6\%), Twitter (7\%) and specialized forums and blogs $(3.5 \%)$ for their image advertisements (Weitzel et al., 2019). The study focused on current employees and found it is necessary to cater to their needs. Additionally, the results may highlight a general tendency among current and prospective hospitality industry employees. Therefore, advertising jobs in the industry might benefit from emphasizing commitment-influencing employer image factors, such as the working atmosphere and task as well as pay attractiveness.

This study contributes to the understanding of how employer image relates to affective occupational commitment in the context of family-run firms in the hospitality industry. As with any academic work, we hope that this work stimulates other researchers to study the issue of affective commitment and current employees of family businesses. More extensive research is certainly needed in this important area.

\section{References}

Aiken, L.S. and West, S.G. (1996), Multiple Regression: Testing and Interpreting Interactions, 4. Print, Sage Publications. Newbury Park CA.

Akuratiya, D.A. (2017), "Influence of perceived employer branding on perceived organizational culture employee identity and employee commitment", International Journal of Scientific \& Technology Research, Vol. 6 No. 8, pp. 148-153.

Alniacik, U., Cigerim, E., Akcin, K. and Bayram, O. (2011), "Independent and joint effects of perceived corporate reputation, affective commitment and job satisfaction on turnover intentions", Procedia - Social and Behavioral Sciences, Vol. 24, pp. 1177-1189.

Ambler, T. and Barrow, S. (1996), "The employer brand", Journal of Brand Management, Vol. 4 No. 3 , pp. 185-206.

Astrachan, C.B., Botero, I., Astrachan, J.H. and Prügl, R. (2018), "Branding the family firm: a review, integrative framework proposal, and research agenda", Journal of Family Business Strategy, Vol. 9 No. 1, pp. 3-15.

Backhaus, K. and Tikoo, S. (2004), "Conceptualizing and researching employer branding", Career Development International, Vol. 9 No. 5, pp. 501-517.

Bacon, N. Hoque, K. and Siebert, S. (2013), "Family business people capital", available at: www.ifb.org. uk/media/1353/people_capital_report_june_2013.pdf

Baum, T. (2018), "Sustainable human resource management as a driver in tourism policy and planning: a serious sin of omission?", Journal of Sustainable Tourism, Vol. 26 No. 6, pp. 873-889.

Baum, M. and Kabst, R. (2013), "How to attract applicants in the atlantic versus the Asia-Pacific region? A cross-national analysis on China, India, Germany, and Hungary", Journal of World Business, Vol. 48 No. 2, pp. 175-185. 
Becker, H.S. (1960), "Notes on the concept of commitment", American Journal of Sociology, Vol. 66 No. 1, pp. 32-40.

Bertrand, M. and Schoar, A. (2006), "The role of family in family firms", Journal of Economic Perspectives, Vol. 2, pp. 73-96.

Brown, R.B. (1996), "Organizational commitment: clarifying the concept and simplifying the existing construct typology", Journal of Vocational Behavior, Vol. 49 No. 3, pp. 230-251.

Brown, E.A., Thomas, N.J. and Bosselman, R.H. (2015), "Are they leaving or staying: a qualitative analysis of turnover issues for generation $\mathrm{Y}$ hospitality employees with a hospitality education", International Journal of Hospitality Management, Vol. 46, pp. 130-137.

Bryman, B. and Bell, E. (2011), Business Research Methods, 3rd ed., Oxford University Press Oxford.

Cable, D.M. and Turban, D.B. (2001), "Establishing the dimensions, sources and value of job seekers' employer knowledge during recruitment", Research in Personnel and Human Resources Management, Emerald Group Publishing Limited. Bingley, pp. 115-163.

Chang, C.C., Chiu, C.M. and Chen, C.A. (2010), "The effect of TQM practices on employee satisfaction and loyalty in government", Total Quality Management \& Business Excellence, Vol. 21 No. 12, pp. 1299-1314.

Chrisman, J., Steier, L.P. and Chua, J.H. (2008), "Toward a theoretical basis for understanding the dynamics of strategic performance in family firms", Entrepreneurship Theory and Practice, Vol. 32 No. 6, pp. 935-947.

Chua, J.H., Chrisman, J.J. and Sharma, P. (1999), "Defining the family business by behavior", Entrepreneurship Theory and Practice, Vol. 23 No. 4, pp. 19-39.

Cohen, A. (2003), Multiple Commitments in the Workplace: An Integrative Approach, Erlbaum, ahwah, NJ.

Cortina, J.M. (1993), "What is coefficient alpha? An examination of theory and applications", Journal of Applied Psychology, Vol. 78 No. 1, pp. 98-104.

Craig, J.B., Dibrell, C. and Davis, P.S. (2008), "Leveraging family-based brand identity to enhance firm competitiveness and performance in family businesses", Journal of Small Business Management, Vol. 46 No. 3, pp. 351-371

Danler, M. and Zehrer, A. (2017), "Die wahrnehmung der arbeitgebermarke von familienunternehmen am beispiel von studierenden", Forschungsforum Der Österreichischen Fachhochschulen, Vol. 2017.

Davies, G., Mete, M. and Whelan, S. (2018), "When employer brand image aids employee satisfaction and engagement", Journal of Organizational Effectiveness: People and Performance, Vol. 5 No. 1, pp. 64-80.

Dhaenens, A.J., Marler, L.E., Vardaman, J.M. and Chrisman, J.J. (2018), "Mentoring in family businesses: toward an understanding of commitment outcomes", Human Resource Management Review, Vol. 28 No. 1, pp. 46-55.

Dhar, R.L. (2015), "Service quality and the training of employees: the mediating role of organizational commitment”, Tourism Management, Vol. 46, pp. 419-430.

Deery, M. and Jago, L. (2009), "A framework for work-life balance practices: addressing the needs of the tourism industry", Tourism and Hospitality Research, Vol. 9 No. 2, pp. 97-108.

Dutton, J.E. and Dukerich, J.M. (1991), "Keeping an eye on the mirror: image and identity in organizational adaptation", Academy of Management Journal, Vol. 34 No. 3, pp. 517-554.

Ewing, M.T., Pitt, L.F., de Bussy, N.M. and Berthon, P. (2002), "Employment branding in the knowledge economy", International Journal of Advertising, Vol. 21 No. 1, pp. 3-22.

Ferreira, A.I., Martinez, L.F., Lamelas, J.P. and Rodrigues, R.I. (2017), "Mediation of job embeddedness and satisfaction in the relationship between task characteristics and turnover: a multilevel study in portuguese hotels", International Journal of Contemporary Hospitality Management, Vol. 29 No. 1, pp. 248-267.

Gómez-Mejia, L.R., Haynes, K.T., Núñez-Nickel, M., Jacobson, K.J. and Moyano-Fuentes, J. (2007), "Socioemotional wealth and business risks in family-controlled firms: evidence from spanish olive oil mills", Administrative Science Quarterly, Vol. 52 No. 1, pp. 106-137.

Hair, J., Anderson, R., Tatham, R. and Black, W. (1998), Multivariate Data Analysis, Prentice Hall, Upper Saddle River, NJ. 
Hauswald, H., Hack, A., Franz, W. and Patzelt, H. (2016), "Attracting new talent to family firms: who is attracted and under what conditions?", Entrepreneurship Theory and Practice, Vol. 40 No. 5, pp. 963-989.

Herrbach, O. and Mignonac, K. (2004), "How organisational image affects employee attitudes", Human Resource Management Journal, Vol. 14 No. 4, pp. 76-88.

Ineson, E.M., Benke, E. and Laszlo, J. (2013), "Employee loyalty in hungarian hotels", International Journal of Hospitality Management, Vol. 32, pp. 31-39.

Ito, J.K., Brotheridge, C.M. and McFarland, K. (2013), "Examining how preferences for employer branding attributes differ from entry to exit and how they relate to commitment, satisfaction, and retention", Career Development International, Vol. 18 No. 7, pp. 732-752.

Jain, A.K., Giga, S.I. and Cooper, C.L. (2009), "Employee wellbeing, control and organizational commitment”, Leadership \& Organization Development Journal, Vol. 30 No. 3, pp. 256-273.

Jauhari, V., Bharwani, S. and Butt, N. (2012), "Challenges for the global hospitality indus-try: an HR perspective", Worldwide Hospitality and Tourism Themes, Vol. 4 No. 2, pp. 150-162.

Johnson, R.E., Chang, C.H. and Yang, L.Q. (2010), "Commitment and motivation at work: the relevance of employee identity and regulatory focus", Academy of Management Review, Vol. 35 No. 2, pp. 226-245.

Kachaner, N. Stalk, G. and Bloch, A.J. (2012), "What you can learn from family business", available at: https://hbr.org/2012/11/what-you-can-learn-from-family-business

Kazlauskaite, R., Buciuniene, I. and Turauskas, L. (2006), "Building employee commitment in the hospitality industry", Baltic Journal of Management, Vol. 1 No. 3, pp. 300-314.

Khanolkar, R.S. (2013), "Influence of employer branding on satisfaction and commitment of generation $Y$ employees", IOSR Journal of Business and Management, Vol. 1, pp. 13-18.

Kim, N. (2014), "Employee turnover intention among newcomers in travel industry", International Journal of Tourism Research, Vol. 16 No. 1, pp. 56-64.

Kimpakorn, N. and Tocquer, G. (2009), "Employees' commitment to brands in the service sector: luxury hotel chains in Thailand", Journal of Brand Management, Vol. 16 No. 8, pp. 532-544.

Krappe, A., Goutas, L. and Schlippe, A. (2011), "The 'family business brand': an en-quiry into the construction of the image of family businesses”, Journal of Family Business Management, Vol. 1 No. 1, pp. 37-46.

Kurd, P., Medeni, T., Medeni, T. and Sağsan, M. (2017), "Effects of occupational commitment on corporate reputation: an empirical test for a hospital case in North Cyprus", International Journal of Organizational Leadership, Vol. 6 No. 1, pp. 17-31.

Lacher, R.G. and Oh, C.O. (2012), "Is tourism a low-income industry? Evidence from three coastal regions", Journal of Travel Research, Vol. 51 No. 4, pp. 464-472.

Leekha, A., Chhabra, N. and Sharma, S. (2014), "Employer branding: strategy for improving employer attractiveness", International Journal of Organizational Analysis, Vol. 22 No. 1, pp. 48-60.

Leiß, G. and Zehrer, A. (2018), "Intergenerational communication in family firm succession", Journal of Family Business Management, Vol. 8 No. 1, pp. 75-90.

Lievens, F. and Slaughter, J.E. (2016), "Employer image and employer branding: what we know and what we need to know", Annual Review of Organizational Psychology and Organizational Behavior, Vol. 3 No. 1, pp. 407-440.

Lin, M.-Y., Chiang, C.-F. and Wu, K.-P. (2018), "How hospitality and tourism students choose careers: influences of employer branding and applicants' customer orien-tation", Journal of Hospitality \& Tourism Education, Vol. 30 No. 4, pp. 229-240.

Mandl, I. (2008), "Overview of family business relevant issues", Final Report. KMU Forschung Austria.

Martin, G. and Gómez-Mejia, L. (2016), "The relationship between socioemotional and financial wealth”, Management Research: Journal of the Iberoamerican Academy of Management, Vol. 14 No. 3.

Maxwell, R. and Knox, S. (2009), "Motivating employees to 'live the brand': a comparative case study of employer brand attractiveness within the firm", Journal of Marketing Management, Vol. 25 No. 9-10, pp. 893-907.

Mehmood, N., Ahmad, U.N.B.U., Irum, S. and Ashfaq, M. (2016), "Job satisfaction, affective commitment, and turnover intentions among front desk staff: evidence from Pakistan", International Review of Management and Marketing, Vol. 6 No. 4S, pp. 305-309. 
Mercurio, Z.A. (2015), "Affective commitment as a core essence of organizational commitment: an integrative literature review", Human Resource Development Review, Vol. 14 No. 4, pp. 389-414.

Meyer, J.P. and Allen, N.J. (1991), "A three-component conceptualization of organizational commitment", Human Resource Management Review, Vol. 1 No. 1, pp. 61-89.

Meyer, J.P. and Herscovitch, L. (2001), "Commitment in the workplace: toward a general model", Human Resource Management Review, Vol. 11 No. 3, pp. 299-326.

Meyer, J.P. and Maltin, E.R. (2010), "Employee commitment and well-being: a critical review, theoretical framework and research agenda", Journal of Vocational Behavior, Vol. 77 No. 2, pp. 323-337.

Meyer, J.P., Allen, N.J. and Smith, C.A. (1993), "Commitment to organizations and occupations: extension and test of a three-component conceptualization", Journal of Applied Psychology, Vol. 78 No. 4, p. 538.

Meyer, J.P., Becker, T.E. and Van Dick, R. (2006), "Social identities and commitments at work: toward an integrative model”, Journal of Organizational Behavior, Vol. 27 No. 5, pp. 665-683.

Mowday, R.T., Steers, R.M. and Porter, L.W. (1979), "The measurement of organizational commitment", Journal of Vocational Behavior, Vol. 14 No. 2, pp. 224-247.

Mooney, S.K., Harris, C. and Ryan, I. (2016), "Long hospitality careers - a contradiction in terms?", International Journal of Contemporary Hospitality Management, Vol. 28 No. 11, pp. 2570-2588.

O'Reilly, C.A. and Chatman, J. (1986), "Organizational commitment and psychological attachment: the effects of compliance, identification, and internalization on prosocial behavior", Journal of Applied Psychology, Vol. 71 No. 3, p. 492

Peters, M. and Kallmuenzer, A. (2018), "Entrepreneurial orientation in family firms: the case of the hospitality industry", Current Issues in Tourism, Vol. 21 No. 1, pp. 21-40.

Porter, L.W., Steers, R.M., Mowday, R.T. and Boulian, P.V. (1974), "Organizational commitment, job satisfaction, and turnover among psychiatric technicians", Journal of Applied Psychology, Vol. 59 No. 5, pp. 603.

Priyadarshi, P. (2011), "Employer brand image as predictor of employee satisfaction, affective commitment \& turnover", Indian Journal of Industrial Relations, Vol. 1, pp. 510-522.

Rego, A., Leal, S., Cunha, M.P., Faria, J. and Pinho, C. (2010), "How the perceptions of five dimensions of corporate citizenship and their inter-inconsistencies predict affective commitment", Journal of Business Ethics, Vol. 94 No. 1, pp. 107-127.

Richardson, S. (2010), "Generation Y's perceptions and attitudes towards a career in tourism and hospitality", Journal of Human Resources in Hospitality \& Tourism, Vol. 9 No. 2, pp. 179-199.

Sieger, P., Bernhard, F. and Frey, U. (2011), "Affective commitment and job satisfaction among nonfamily employees: investigating the roles of justice perceptions and psychological ownership", Journal of Family Business Strategy, Vol. 2 No. 2, pp. 78-89.

Sivertzen, A.M., Nilsen, E.R. and Olafsen, A.H. (2013), "Employer branding: employer attractiveness and the use of social media", Journal of Product \& Brand Management, Vol. 22 No. 7, pp. 473-483.

Snape, E. and Redman, T. (2003), "An evaluation of a three-component model of occupational commitment: dimensionality and consequences among United Kingdom human resource management specialists", Journal of Applied Psychology, Vol. 88 No. 1, p. 152.

Sokro, E. (2012), "Impact of employer branding on employee attraction and retention", European Journal of Business and Management, Vol. 4 No. 18, pp. 164-173.

Solinger, O.N., Van Olffen, W. and Roe, R.A. (2008), "Beyond the three-component model of organizational commitment", Journal of Applied Psychology, Vol. 93 No. 1, p. 70.

Stadler, M. Wakolbinger, F. and Haigner, S.D. (2016), "Bedeutung des tourismus für Tirol", Berechnung der Wertschöpfung, Beschäftigung und Einkommen. Abgerufen am 03.02.2019 von, available at: www. tirol.gv.at/fileadmin/themen/statistik-budget/statistik/downloads/PNr104_GAW_Bedeutung_Tourismus_ fuer_Tirol.pdf

Stewart, A. (2003), "Help one another, use one another: toward an anthropology of family business", Entrepreneurship Theory and Practice, Vol. 27 No. 4, pp. 383-396.

Swab, R.G., Sherlock, C., Markin, E. and Dibrell, C. (2020), "SEW" what do We know and where do we go? A review of socioemotional wealth and a way forward", Family Business Review, Vol. 33 No. 4, pp. 424-445. 
Tang, T.L.P., Cunningham, P.H., Frauman, E., Ivy, M.I. and Perry, T.L. (2012), "Attitudes and occupational commitment among public personnel: differences between baby boomers and Gen-Xers", Public Personnel Management, Vol. 41 No. 2, pp. 327-360.

Tuzunkan, D. (2018), "Undergraduate tourism students' perceptions and attitudes towards tourism industry: the case of daejeon, South Korea", GeoJournal of Tourism and Geosites, Vol. 21 No. 1, pp. 103-111.

Weng, Q. and McElroy, J.C. (2012), "Organizational career growth, affective occupational commitment and turnover intentions", Journal of Vocational Behavior, Vol. 80 No. 2, pp. 256-265.

Yousef, D.A. (2017), "Organizational commitment, job satisfaction and attitudes toward organizational change: a study in the local government", International Journal of Public Administration, Vol. 40 No. 1, pp. 77-88.

Zellweger, T.M., Eddleston, K.A. and Kellermanns, F.W. (2010), "Exploring the concept of familiness: introducing family firm identity", Journal of Family Business Strategy, Vol. 1 No. 1, pp. 54-63.

\section{Further reading}

Podsakoff, P.M. and Organ, D.W. (1986), "Self-reports in organizational research: problems and prospects", Journal of Management, Vol. 12 No. 4, pp. 531-544.

\section{About the authors}

Katrin Schwaiger is a researcher at the Management Center Innsbruck and a PhD student at the University of Cologne at the Faculty of Geography. Her research interests are in tourism geography, environment-centered geography, management, entrepreneurship and human resources, family businesses and small-/medium-sized businesses and natural hazards. She focuses particularly on employee commitment in the tourism industry with specific regard to individual businesses and destinations in Austria and Germany. Katrin Schwaiger is the corresponding author and can be contacted at: kschwaig@smail. uni-koeln.de

Anita Zehrer is a professor at the Management Center Innsbruck. She is the head of the Family Business Center within the institute. Her research focuses on family business research. Specific topics of research include the hospitality industry, employer branding, organizational resilience, risk and succession in family businesses and employee commitment.

For instructions on how to order reprints of this article, please visit our website: www.emeraldgrouppublishing.com/licensing/reprints.htm

Or contact us for further details: permissions@emeraldinsight.com 